diabetic autonomic neuropathy. BMf 1982;285:916-8.

13 Levy DM, Rowley DA, Abraham RR. Changes in cholinergic sweat gland activation in diabetic neuropathy identified by computerised sweatspot analysis. Diabetologia 1991;34:807-12.

14 Levy DM, Reid G, Abraham RR, Rowley DA. Assessment of basal and stimulated sweating in diabetes using a direct-reading computerized sudorometer. Diabetic Med direct-reading com

15 Abraham RR, Abraham RM, Wynn V. Autonomic and electrophysiological studies in patients with signs or symptoms of diabetic neuropathy. Electroencephalogr Clin Neurophysiol 1986;63:223-30.

16 Levy DM, Abraham RR, Abraham RM. Small- and largefibre involvement in early diabetic neuropathy: a study with the medial plantar response and sensory thresholds. Diabetes Care 1987;10:441-7.

17 Satchell PM, Seers CP. Evoked skin sympathetic nerve responses in man. $\mathcal{F}$ Neurol Neurosurg Psychiatry 1987;
50:1015-21.

18 Halar EM, DeLisa JA, Brozowich FV. Nerve conduction velocity: relationship of skin, subcutaneous and intramuscular temperature. Arch Phys Med Rehabil 1980;61: 199-203.

19 Low PA. Quantitation of autonomic responses. In: Dyck PJ, Thomas PK, Lambert EH, Bunge R, eds. Peripheral neuropathy. Vol 1, 2nd ed. Philadelphia: W B Saunders, 1983:1139-64.

20 Low PA, Caskey PE, Tuck RR, Fealey RD, Dyck PJ Quantitative sudomotor axon reflex test in normal and neuropathic subjects. Ann Neurol 1983;14:573-80.

21 Shahani BT, Day TJ, Cros D, Khalil N, Kneebone CS. RR interval variation and the sympathetic skin response in the assessment of autonomic function in peripheral neuroassessment of autonomic function in

22 Fagius J, Wallin BG. Sympathetic reflex latencies and conduction veocities in normal man. $\mathcal{f}$ Neurol Sci 1980;47:433-8

\section{The Anatomy Lesson of Dr Joan Deyman, by Rembrandt (1606-69)}

On the 8 November 1723 the greater part of this painting was destroyed by fire. The dead man in the picture was Joris Fonteijn, known as black Jan, a thief condemned to death on 27 January 1656, and buried on 2 February. That year Rembrandt was commissioned by the surgeons' guild to paint The Anatomy Lesson of Dr Joan Deyman, the same year he applied for cessio bonorum, a form of bankruptcy.

As was usual in such dissections, Deyman has removed the stomach and intestines before beginning the dissection of the brain. The top of the skull is held by the assistant, Gysbrecht Matthijsz Calcoen, a master of the Amsterdam guild of surgeons, and Deyman is in the course of removing the falx cerebri of the dura mater.

This painting was to be placed in the Anatomy Theatre in Amsterdam which was constructed in 1639 in the attic storey of a small meat market building that was used until 1690. The records of the Anatomy Theatre in Amsterdam state that "on January 28th 1656, there was punished Joris Fonteijn of Diest, who by the worshipful lords of the law court was granted to us an anatomical specimen. On the 29th Dr Joan Deyman made his first demonstration on him in the Anatomy Theatre, three lessons altogether". The entry also notes that Dr Deyman was presented with six silver spoons worth 31 guilders and 19 stuivers in recompense for his three demonstrations.
From 1690 until 1841 the painting hung in the surgeons' guild room in the Nieuwe Waag where it was badly damaged by fire. It subsequently passed through several hands and for a period was in the South Kensington Museum in London. It is presently owned by the city of Amsterdam and can be seen in the Rijksmuseum.

The painting is shown on stamps issued by the Republic of Togo in 1968 (Stanley Gibbons 598 and 600, Scott 648 and C93).

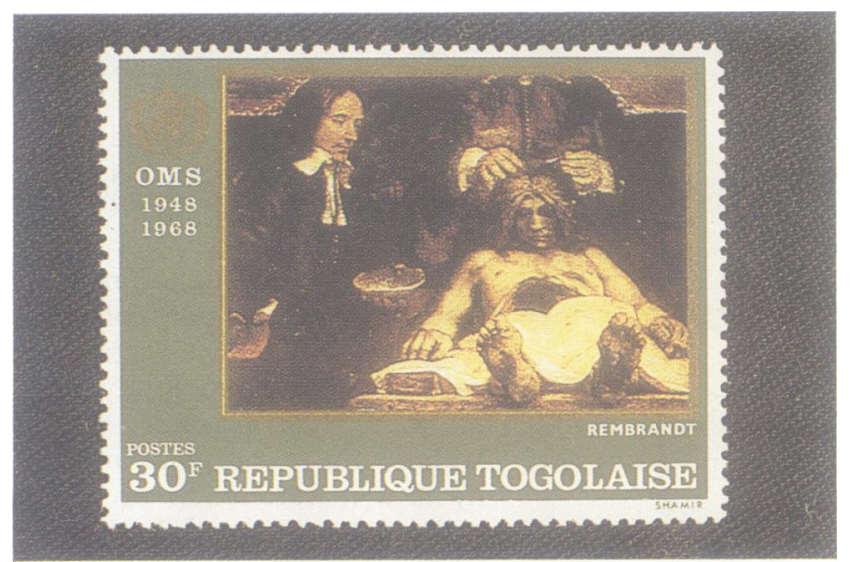

